\title{
A Case of Respiratory Arrest after Tonsillectomy and Adenoidectomy Surgery in a Patient with Rubinstein-Taybi Syndrome
}

\author{
Sung Hee Kim ${ }^{1}$, Jin-Taek Park ${ }^{1}$, Min Joo Kim² ${ }^{2}$ and Yoo-Sam Chung ${ }^{1}$ \\ ${ }^{1}$ Department of Otolaryngology, Asan Medical Center, University of Ulsan College of Medicine, Seoul; and \\ ${ }^{2}$ Department of Otorhinolaryngology-Head and Neck Surgery, Hongik Hospital, Seoul, Korea
}

\section{Rubinstein-Taybi Syndrome 환아에서 편도 및 아데노이드 절제술 후 발생한 호흡정지 1예}

김성희 ${ }^{1} \cdot$ 박진택 $^{1} \cdot$ 김민주 $^{2} \cdot$ 정유삼 ${ }^{1}$

울산대학교 의과대학 서울아산병원 이비인후과학교실, ${ }^{1}$ 홍익병원 이비인후과 ${ }^{2}$

\author{
Received December 16, 2015 \\ Revised January 17, 2016 \\ Accepted January 28, 2016 \\ Address for correspondence \\ Yoo-Sam Chung, MD, PhD \\ Department of Otolaryngology, \\ Asan Medical Center, \\ University of Ulsan \\ College of Medicine, \\ 88 Olympic-ro 43-gil, Songpa-gu, \\ Seoul 05505, Korea \\ Tel $+82-2-3010-3716$ \\ Fax $+82-2-489-2773$ \\ E-mail entysc@gmail.com
}

Rubinstein-Taybi syndrome (RTS) is a rare autosomal dominant disorder characterized by mental and growth retardation, craniofacial, vertebral, ocular and cardiac anomalies, gastroesophageal reflux, and difficult airway management. Patients with this syndrome can also experience upper airway obstruction during sleep, which is caused by hypotonia and the abnormal anatomy of the oropharynx and airways, and become susceptible to obstructive sleep apnea. In our case, respiratory arrest developed in an RTS patient who had undergone Tonsillectomy and Adenoidectomy (T\&A) surgery. It is the first report of respiratory arrest after T\&A surgery in a young child with RTS

Korean J Otorhinolaryngol-Head Neck Surg 2016;59(10):742-5

Key Words Adenoidectomy · Airway obstruction · Rubinstein-Taybi syndrome ·

Sleep apnea $\cdot$ Tonsillectomy.

\section{Introduction}

Rubinstein-Taybi syndrome (RTS) is a rare autosomal dominant disorder caused by either a micro deletion at $16 \mathrm{p} 13.3$ or mutations in the cAMP response element-binding protein (CREBBP or CBP) or E1A-binding protein p300 (EP300) genes (at 22q13). ${ }^{1)}$ The incidence of the syndrome is estimated to be one in every 300000 newborns in Western countries. There is an equal male to female incidence. ${ }^{2)}$ In Korea, some cases of RTS might go unrecognized or be underreported, because only a few cases have been reported so far. ${ }^{3)}$

The risks of general anesthesia in RTS patients, including aspiration pneumonia and cardiac arrhythmia are well known. However, as far as we know, the case reported in this study is the first one to record respiratory arrest after Tonsillectomy and Adenoidectomy (T\&A) surgery in a patient with RTS.

\section{Case}

The patient was a 6-year-old RTS male weighing $22 \mathrm{~kg}$ (75th percentile) with a height of $107 \mathrm{~cm}$ (3-10th percentile) who was not on taking any particular medication. According to the Korean-Wechsler Intelligence Scale for Children-IV classification, he was considered to have moderate mental retardation (Full Scale Intelligence Quotient 47). He suffered from snoring for four years, although as there was no effect on his medical treatment, he visited our hospital for a tonsillectomy (peritonsillar hypertrophy, grade I) and adenoidectomy (adenoid vegetation, grade III). Even when tonsillar hypertrophy is grade I, the reason we decided to perform the surgery is that 
there are differences between the subjective tonsil size and the real palatine tonsil size and T\&A is one of the treatment options of obstructive sleep apnea (OSA) in children who are obese regardless of their tonsil size. Another reason is that if the size of the adenoids is larger, the effect of the surgery is better when we do the tonsillectomy and adenoidectomy together because lymphoid tissue is left behind, which may cause continued obstruction.

He underwent orchiopexy and hydrocele excision in 2008, and bilateral lateral rectus resection in 2012 at our hospital under general anesthesia, but no postoperative complications were observed at that time. In conformity with his RTS status, he had a narrow forehead, a broad thumb, a big toe, strabismus, mild scoliosis, and bilateral ptosis (Fig. 1). Chest examinations using X-ray radiography, electrocardiography, and echocardiography did not reveal any abnormalities, but airway management problems were expected because he was classified as Mallampati class III.

He was attached to monitoring equipment, including an electrocardiogram, an oxygen saturation monitor, and a noninvasive blood pressure monitoring machine on arrival at the operating room. The vital signs during the surgery were 80-120/ 40-60 mm Hg (BP), 100-160 beats/min (HR), 18-22 times/ $\min (\mathrm{RR})$, and $99-100 \%$ (SpO2). He had no history of a tonsillar abscess, so adhesion was minimal. The tonsil was clamped with a tooth forceps, and a mucosal incision was done through the anterior pillar and the posterior pillar with a monopolar coagulator. After identification of the tonsillar capsule, dissection was performed between the tonsillar capsule and bed with a monopolar coagulator. Bleeding was minimal and well controlled by the bipolar coagulator. Adenoidectomy was done using the transoral endoscopic approach. Choanal obstruction by adenoid tissue was observed, but a tubal tonsil was absent. The adenoid was removed using a microdebrider and bleeding was controlled with a suction coagulator. Before transfer to the re- covery room, ventolin puffs were administered four times to control respiratory wheezing, which occurred after the recovery of self-respiration.

During the general ward round, he showed no problems in breathing. However, during sleep at night, oxygen saturation dropped below $90 \%$. Thus, oxygen ( $2 \mathrm{~L} / \mathrm{min}$ ) via a nasal prong was administered and oxygen saturation was closely monitored. The day after surgery at about 3:00 AM, the patient experienced difficulty in breathing with coarse breathing sounds and wheezing. Oxygen saturation was maintained at 94-95\% by administering oxygen $(5 \mathrm{~L} / \mathrm{min})$ via a nasal prong. Thirty minutes later, his lips turned pale and oxygen saturation dropped below 70\%. A pediatric medical alert team was called, and oxygen saturation dropped further to below 30\%. Full oxygenation (15 L/min) with ambu-bagging was applied, after which oxygen saturation rose slowly, but failed to reach 95-98\%. The pediatric medical alert team tried to perform intubation with a cuffed tube (reinforced $5.0 \mathrm{~mm}$ ), but it was impossible to advance the tube around the subglottic area; therefore, intubation was performed with the one down sized cuffed tube (reinforced $4.5 \mathrm{~mm}$ ). After successful intubation, he was transferred to an intensive care unit for ventilation.

Two days after surgery, ventilator weaning was done and the patient was supported with oxygen $(5 \mathrm{~L} / \mathrm{min})$ administered via a T-piece. Feeding with total parenteral nutrition was supported, and his vital signs were stable, but he had moderate fever $\left(39^{\circ} \mathrm{C}\right)$; thus, antibiotics were administered. Four days after surgery, we performed extubation and applied high flow (10 $\mathrm{L} / \mathrm{min}$ ) oxygen via a nasal canula. Five days after surgery, he took sips of water and oral feeding was attempted. Eight days after surgery, he was discharged with no complications, his appetite was good, sleep apnea had improved, and his chest showed symmetric expansion without retraction; however, mild coarse breathing sounds could still be heard.

When he revisited our hospital four days after his discharge,
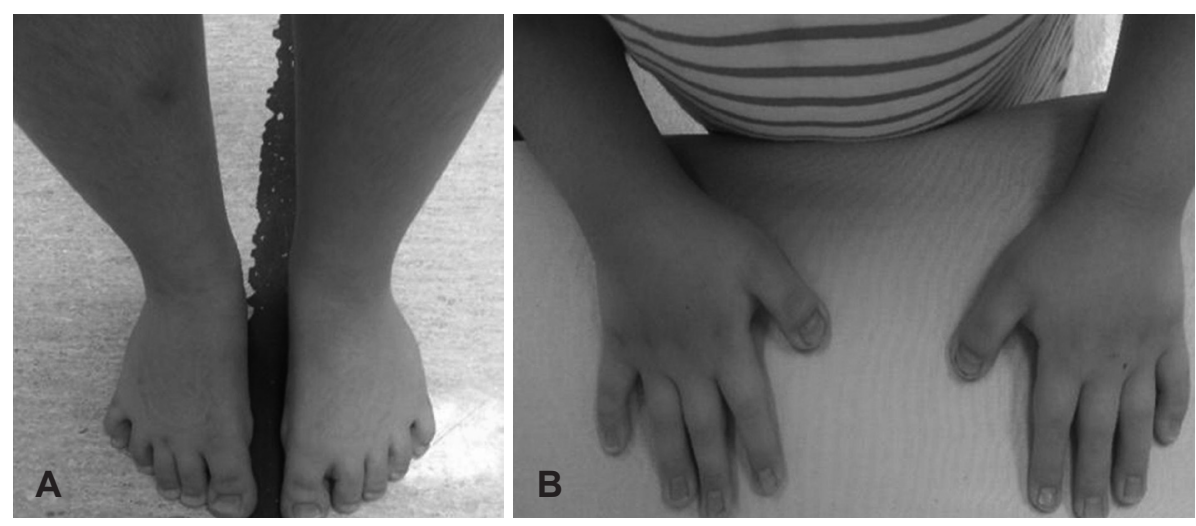

Fig. 1. An image showing the broad big toes $(A)$ and broad thumbs $(B)$. 

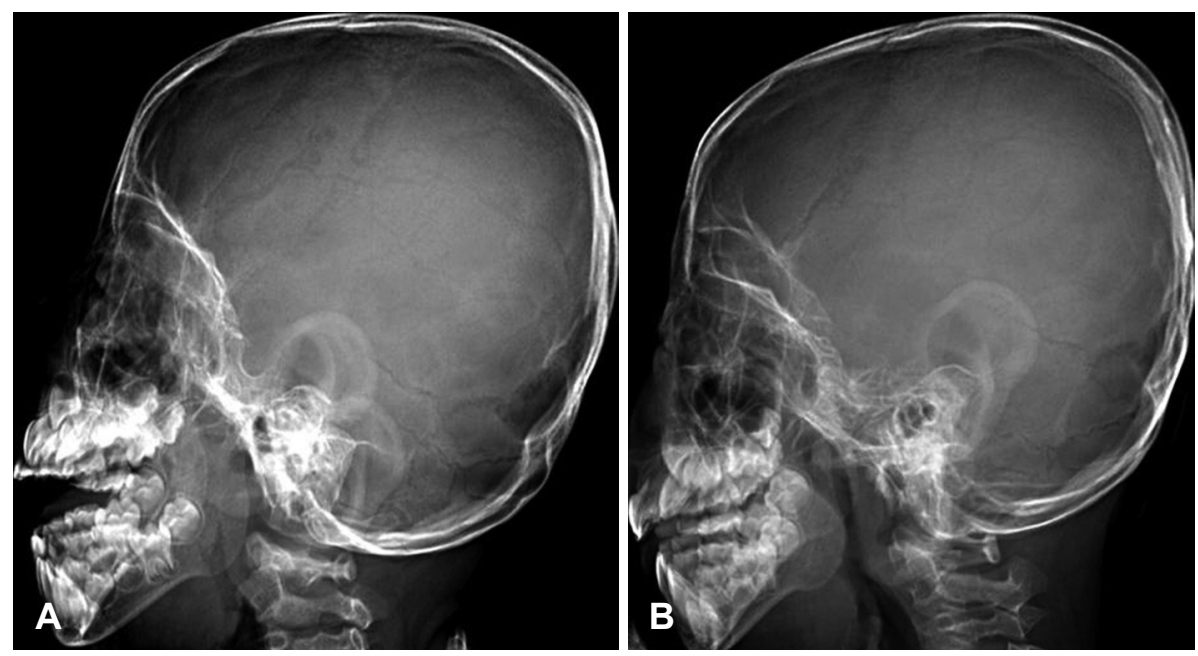

Fig. 2. Lateral image of paranasal sinus view. Preoperative image shows narrowed upper airway $(A)$ and postoperative image shows slightly widened upper airway (B).

his snoring had improved but it still occurred when he lay in a supine position. The surgical area showed evidence of advanced healing. At the time of his six-month follow-up, he showed a slightly increased he diameter of upper airway on the paranasal sinus view (Fig. 2).

Two years after his surgery, he underwent polysomnography (PSG) because his snoring symptoms were once again aggravated. The apnea-hypoapnea index (AHI) was 110.8 per hour and which indicated severe obstructive sleep apnea. Therefore, applied continuous positive airway pressure (CPAP) was applied and the last positive air pressure data showed 6.6 per hour of AHI.

\section{Discussion}

Children with RTS can experience upper airway obstruction during sleep because of hypotonia, the unusual anatomy of their oropharynx and airways (small nasal passages, retrognathia, micrognathia, and hypertrophy of the tonsils and adenoids), and obesity. ${ }^{4)}$ Appropriate medical and surgical treatments should be applied and performed with caution because individuals with RTS have airway management and anesthesia issues. ${ }^{5)}$

In this patient, we performed a pre-operative pediatric consultation because the risk of general anesthesia is well known in RTS patients. Therefore, we used careful management procedures that are typically used to control aspiration pneumonia and cardiac arrhythmia. We expected no additional risk during the surgery with the patient under general anesthesia as the patient had not experienced any problems during a previous surgery. No complications occurred during or immediately after the surgery and the patient had no difficulty breathing, howev- er, on the day after the surgery, he began to increasingly suffer from breathing problems and went into respiratory arrest.

We believe that the cause of respiratory arrest in this rare case was not only due to the general anesthesia, but also to other causes.

First, we overlooked management of his severe OSA. According to the practice guidelines for the perioperative management of patients with OSA, ${ }^{6}$ preoperative initiation of CPAP should be considered, particularly if the OSA is severe. Perioperatively, it should be considered in selecting intraoperative medications which affect the post-operative respiratory compromise. Postoperatively, supplemental oxygen should be administered continuously to all patients who are at increased perioperative risk for OSA until they are able to maintain their baseline oxygen saturation while breathing room air. When feasible, CPAP or noninvasive positive pressure ventilation should be continuously administered to patients who were using these modalities preoperatively, ${ }^{7)}$ unless they are contraindicated by the surgical procedure. Therefore, patients with suspected OSA need to be evaluated according to his/her medical records review, patient/family interview, and screening protocol, in addition to a physical examination and also PSG in order to identify OSA. ${ }^{8)}$

Second, T\&A involves upper airway surgery and may cause upper airway edema which makes airway obstruction. Postoperative oropharyngeal edema usually manifests itself on the day after surgery and then progressively declines on the third day following surgery. ${ }^{9)}$ Intravenous dexamethasone injection is helpful for reducing postoperative oropharyngeal edema and pain. ${ }^{10)}$ In our patient, we used intravenous dexamethasone preoperatively. For another method of alternative airway management, extubation can be delayed one 
or two days after surgery.

Third, children with RTS have hypotonic upper airways that causes their laryngeal wall to easily collapse and it is, therefore, possible to accelerate the occurrence of respiratory arrest after T\&A surgery.

T\&A is usually helpful in some children with RTS; however, it is worthwhile taking into consideration that there is a risk of respiratory arrest in these patients after surgery. Therefore, postoperative CPAP for airway stents and postoperative intensive care unit management should be implemented in order to ensure a quick response in emergency situations as well as optimal surgery outcomes.

It is difficult to prove the causal relationship between RTS and the respiratory arrest mechanism, however, our report has a clinical impact as much attention should be given in order to prevent respiratory arrest in such patients. We have never experienced respiratory arrest after T\&A surgery in normal patients who had OSA. As this was the first reported patient, we thought it to be significant.

\section{REFERENCES}

1) Coupry I, Roudaut C, Stef M, Delrue MA, Marche M, Burgelin I, et al. Molecular analysis of the CBP gene in 60 patients with Rubinstein-
Taybi syndrome. J Med Genet 2002;39(6):415-21.

2) Cirillo RL Jr. Pediatric case of the day. Rubinstein-Taybi syndrome. Radiographics 1997;17(6):1604-5.

3) Kim SH, Lim BC, Chae JH, Kim KJ, Hwang YS. A case of RubinsteinTaybi Syndrome with a CREBbinding protein gene mutation. Korean J Pediatr 2010;53(6):718-21.

4) Allanson JE. Rubinstein-Taybi syndrome: the changing face. Am J Med Genet Suppl 1990;6:38-41.

5) Wiley S, Swayne S, Rubinstein JH, Lanphear NE, Stevens CA. Rubinstein-Taybi syndrome medical guidelines. Am J Med Genet A 2003;119A(2):101-10.

6) Fahlenkamp A, Rossaint R, Coburn M; American Society of Anesthesiologists Task Force. [Perioperative management of patients with obstructive sleep apnea : update on the practice guidelines of the American Society of Anesthesiologists Task Force]. Anaesthesist 2014;63(6):511-3.

7) Park CH, Shim HJ, Kim EJ, Ahn YM. A case of treatment in obstructive sleep apnea syndrome in children with lingual tonsillar hypertrophy. Korean J Otorhinolaryngol-Head Neck Surg 2008;51 (6):562-5.

8) Won TB. Contemporary methods of upper airway evaluation in obstructive sleep apnea patients. Korean J Otorhinolaryngol-Head Neck Surg 2013;56:7-13.

9) Fischer M, Horn IS, Quante M, Merkenschlager A, Schnoor J, Kaisers UX, et al. Respiratory complications after diode-laser-assisted tonsillotomy. Eur Arch Otorhinolaryngol 2014;271(8):2317-24.

10) Faiz SH, Rahimzadeh $P$, Alebouyeh MR, Sedaghat M. A Randomized Controlled Trial on Analgesic Effects of Intravenous Acetaminophen versus Dexamethasone after Pediatric Tonsillectomy. Iran Red Crescent Med J 2013;15(11):e9267. 